\title{
RESEPSI KESADARAN BERBAHASA SECARA KRITIS DALAM AKTIVITAS PENULISAN FIKSI GURU DAN SISWA
}

\author{
Suminto A. Sayuti, Esti Swatika Sari, dan Beniati Lestyarini \\ Fakultas Bahasa dan Seni Universitas Negeri Yogyakarta \\ email: b_lestya@yahoo.com
}

\begin{abstract}
Abstrak
Penelitian ini bertujuan mendeskripsikan resepsi kesadaran berbahasa secara kritis (Critical Language Awareness) dalam proses penulisan karya fiksi pada guru dan siswa SMA se-DIY. Penelitian ini merupakan penelitian analisis konten yang didukung data kualitatif hasil Focus Group Discussion (FGD). Subjek penelitian adalah guru dan siswa SMA se-DIY. Analisis data dalam proses pemaknaan karya guru dan siswa berdasarkan unsur-unsur CLA. Hasil penelitian menunjukkan bahwa'resepsi kesadaran berbahasa secara kritis guru dan siswa dalam menulis fiksi tercermin dalam proses maupun hasil. Guru masih kurang optimal dalam pengembangan metode, pemanfaatan media, dan pemilihan sistem penilaian dalam pembelajaran penulisan fiksi. Sebagian besar karya siswa belum menampakkan kesadaran pentingnya kekuatan bahasa dan posisi diri sebagai penulis.
\end{abstract}

Kata kunci: resepsi, kesadaran berbahasa secara kritis, dan penulisan fiksi

\section{THE RECEPTION OF CRITICAL LANGUAGE AWARENESS IN TEACHERS' AND STUDENTS' FICTION WRITING ACTIVITIES}

\begin{abstract}
This study aims to describe the reception of critical language awareness (CLA) in the fiction writing process among senior high school (SHS) teachers and students. It was a content analysis supported by qualitative data collected through focus group discussions. The subjects were SHS teachers and students in Yogyakarta Special Territory. The data analysis in the process of interpreting meanings of their works was based on the CLA elements. The findings showed that their reception of CLA in fiction writing was reflected in both the process and the outcome. The teachers were still not optimal enough in developing methods, using media, and selecting the assessment system in the learning of fiction writing. Most of the students' works did not reveal the awareness of the importance of language power and self-position as writers.
\end{abstract}

Keywords: reception, Critical Language Awareness, fiction writing

\section{PENDAHULUAN}

Ilmu pengetahuan semakin melaju tanpa titik henti. Pusaran globalisasi juga memberikan tantangan pada manusia untuk merespon segala perubahan secara cepat dan tepat. Perubahan akan selesai ketika paradigma berhenti (Fuller dalam Yood, 2005: 4). Bidang pendidikan yang berperan sebagai wadah sekaligus pencipta agen perubahan (agent of change) menjadi sebuah keniscayaan untuk terus mengembangkan dan memperkuat kekuatannya dalam menyokong kehidupan manusia.

Tantangan sekaligus kesempatan sebagai pemaknaan positif untuk menjawab perubahan dalam uraian di atas tidak akan bisa terlaksana tanpa adanya jalinan komunikasi yang kuat. Dalam hal ini, bahasa memegang peranan strategisnya sebagai alat untuk berkomunikasi. Berbagai teori interpretasi wacana berkembang bahkan 
saling tumpang tindih. Paradigma baru dalam pendidikan bahasa muncul sebagai jawaban dari beberapa hasil penelitian para ahli bahwa kondisi sosiokultur menjadi poin penting bagi perkembangan paradigma, pendekatan, metode, dan sekaligus tujuan pendidikan bahasa. Kesadaran berbahasa secara kritis (Critical Language Awareness/CLA) yang dikemukakan oleh Fairclaugh (1995: 219) menjadi referensi pendidikan bahasa terkini. Banyak penelitian yang dilakukan berkaitan dengan Language Awareness dan Critical Language Awareness dalam 10 tahun terakhir ini seperti di Kanada, Amerika, Australia, Inggris, dan Afrika yang juga didukung dengan proyek pengembangan tentang Language Awarenss seperti The European Awareness and Intercomprehension $(E U+I)$ Project di Eropa (Svalberg, Agneta M-L, 2007: 301).

Iklim akademis di sekolah senantiasa disiapkan sekaligus dikondisikan untuk memperkuat identitas siswa agar mampu aktif dan progresif. Dalam segala aktivitas sekolah, respons terhadap fenomena sosial, budaya, dan politik baik dalam diskusi ringan, diskusi formal akademis, telaah pustaka (buku dan media massa) maupun kegiatan penulisan diarahkan untuk dilakukan secara komprehensif dan holistik. Hal ini bertujuan untuk menunjukkan bahwa manusia memang tidak dapat terlepas dari lingkungannya sebagai representasi dari karya manusia itu sendiri. Dalam hal ini, sastra menjadi salah satu media tulis untuk menyampaikan respons dari berbagai pengalaman hidup siswa. Dari sastra pula, siswa dapat mempelajari berbagai karakter manusia lengkap dengan gaya dan pilihan hidupnya masing-masing. Melalui kegiatan membaca dan menulis sastra, siswa diharapkan dapat menjadi pribadi yang memiliki karakter kuat dan senantiasa melakukan refleksi dalam hidupnya.

Pembelajaran sastra di sekolah selama ini, termasuk di SMA/MA/SMK, tampak- nya memang masih sangat lemah. Hal ini dapat dilihat dari rendahnya minat baca dan lemahnya kemampuan siswa mengapresiasi karya sastra. Lemahnya pembelajaran sastra di sekolah sebagaimana juga dikeluhkan kalangan sastrawan dapat dilacak dari beberapa segi. Pertama, komitmen pemerintah terlihat kurang serius. Kedua, secara teknis guru-guru bahasa pada umumnya tidak selalu mampu menjadi guru sastra. Ketiga, ada kesenjangan antara karya sastra dan daya pemahaman siswa, bahkan juga guru nonsastrawan. Keempat, implikasi lebih jauh dari kondisi di atas adalah siswa cenderung mejauhi karya-karya sastra, apalagi terhadap karya sastra yang dianggap "aneh'. Tidak heran jika siswa lebih menyukai sastra populer seperti karya Mira W, Ashadi Siregar, bahkan karya Fredy S.

Berdasarkan paradigma baru pembelajaran bahasa serta permasalahan pembelajaran sastra khususnya penulisan fiksi, penelitian untuk melihat sekaligus menganalisis Kesadaran Berbahasa secara Kritis (Critical Language Awareness/ CLA) dalam kegiatan penulisan fiksi siswa sangat penting untuk dilakukan. Penelitian yang ditujukan untuk guru dan siswa SMA se-DIY ini diharapkan akan dapat menjadi dasar bagi pendekatan yang dipakai dalam pembelajaran, khususnya sastra. Hal itu untuk memperkaya pendekatan kontekstual yang sudah diaplikasikan pada pembelajaran sastra saat ini dan pendekatan lain yang sesuai dengan kondisi dan masalah yang dihadapi dalam proses pembelajaran.

Dengan mempertimbangkan konteks pendidikan di Indonesia dan kebutuhan solutif atas banyaknya masalah yang muncul, penelitian ini terfokus untuk melihat bagaimana model pembelajaran sastra, khususnya penulisan fiksi yang sesuai untuk guru dan siswa tingkat SMA. Tingkat SMA dipilih dengan pertimbangan bahwa pada level pendidikan ini, siswa sudah dituntut untuk aktif, mandiri, serta 
mengembangkan kesadaran dan respons mereka terhadap segala fenomena sosial kehidupan sebagai bekal hidup untuk menghadapi tantangan dunia kerja, dunia pergulatan ideologi di kampus, serta dunia masyarakat global dimana persaingan menjadi cara dalam mencapai sesuatu.

Globalisasi membawa dampak yang cukup hebat dalam dunia pendidikan. Manusia harus bisa hidup tidak hanya dengan lingkungan kecil di sekitarnya tetapi juga harus hidup sebagai masyarakat dunia. Hal ini menjadi sebuah tuntutan bagi dunia pendidikan untuk memberikan sumbangsih dalam penciptaan kultur masyarakat global.

Dampak positif globalisasi dapat dilihat terutama dengan berkembangnya ilmu pengetahuan yang teknologi yang sangat pesat. Namun hal-hal negatif sangat mungkin terjadi dan bahkan sudah terjadi. Etnosentris, superior, hegemonik, kesenjangan, dan menilai kelompok lain lebih rendah menjadi hal yang sering terjadi yang merupakan kelemahan dari model cawan lebur (Suyata, 2006: 217). Peristiwa-peristiwa yang berkaitan dengan rasisme seperti di Africa, Amerika (perjuangan orang berkulit hitam) atau bahkan di Indonesia sendiri seperti konflik di Ambon, Kalimantan, Papua juga sampai sekarang masih sering terjadi. Namun, perjuangan kelas-kelas yang terdeskriminasi terutama di Eropa telah membawa keberhasilan gemilang dengan menggunakan sarana literasi (kebahasaan) sebagai alat perjuangan kelas seperti dari beberapa hasil penelitian dalam buku Making Race Visible: Literary Research for Cultural Understanding (Greene dan Perkins, 2003(ed)).

Diskusi tentang kaitan antara bahasa, kekuatan, dan komunitas sebenarya sudah diawali dari sekitar tahun 1970. Kuhn dalam The Structure of Scientific Revolutions (via Yood, 2005: 5) mengatakan bahwa perubahan intelektual dibangun dalam komunitas. Namun Kuhn tidak bisa mem- berikan penjelasan mengenai hubungan rekursif bahwa komunitas akan berperan untuk umum dan untuk dirinya sendiri juga dengan perjuangan yang terus menenrus untuk menemukan makna dan relevansi dalam disiplim akademis. Fuller dalam sumber yang sama mengemukakan konsep "pergerakan sosial" (social movement) sebagai alternatif paradigma. Dalam konsep ini, pengetahuan baru dimaknai dalam konteks perubahan intelektual dan politik dan dalam respon terhadap citra profesi yang diciptakannya sendiri.

Fairclaugh dalam bukunya Critical Language Awareness (1992: 14-15) menyatakan bahwa "CLA is an awareness of the ways in which ideas become naturalized or taken for granted as thruth about the natural and social world and how these truths are tied up with language in use (CLA adalah kesadaran dimana gagasan menjadi netral atau diakui sebagai kebenaran alam dan sosial dan kebenaran ini terikat pada penggunaan bahasa. Tujuan dari CLA adalah untuk mendorong siswa membuka pikiran bahwa bahasa dalam teks adalah sebuah konstruksi sosial dan memberikan pemahaman bahwa bahasa mungkin akan memberikan posisi negative dan positif baik disengaja maupun tidak disengaja.

Dalam sebuah artikelnya yang berjudul "Global Capitalism and Critical Awareness of Language, Fairclaugh menguraikan mengapa CLA sangat penting untuk dikaji.

“..... several key features of late modern society which help make the case for critical awareness of discourse: the relationship between discourse, knowledge, and social change in our 'information' or 'knowledge-based' society; what Smith(1990) has called the 'textually-mediated' nature of contemporary social life; the relationship between discourse and social difference; the commodification of discourse; discourse and democracy $(1999,71)$. 
Alasan pentingnya CLA dari uraian di atas yaitu andanya hubungan antara wacana, pengetahuan, dan perubahan sosial dalam masyarakat yang berdasar pada informasi dan pengetahuan, konsep dari Smith tentang mediasi tekstual dalam kehidupan social sekarang ini, hubungan antara wacana dan perbedaan social, komodifikasi wacana, serta wacana dan demokrasi.

Dalam laporan Higher Education in the Learning Society dari National Committee of Inquiry into Higher Education, 1997 (Fairclaugh, 1999: 80) pendidikan diarahkan pada kemampuan (skill) untuk pembelajaran seumur hidup (lifelong learning). Kemampuan yang dimaksud adalah komunikasi, numerasi, teknologi informasi, dan belajar untuk belajar. Dalam tulisan ini, komunikasi yang diwujudkan dalam bahasa menjadi poin khusus pembahasan yang dikaitkan dengan Critical Language Awareness (CLA).

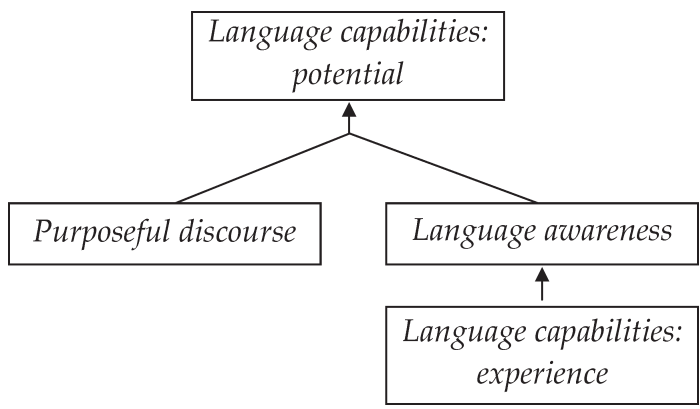

Bagan 1. Model pembelajaran bahasa

Fairclaugh (1992:226) menguraikan bahwa kesadaran berbahasa didasarkan pada kemampuan berbahasa yang didasarkan pada pengalaman. Tujuan pembelajaran yang telah ditentukan dan kesadaran berbahasa akan menjadikan kapabilitas kemampuan berbahasa yang potensial. Fairclaugh menvisualisasikan model pembelajaran bahasa seperti pada bagan 1 .

Dalam pemahaman tentang Kesadaran Berbahasa secara Kritis, siswa diarahkan untuk menjadi etnografer bahasa dan budaya. Siswa tidak hanya menjadi konsumen pengetahuan tetapi menjadi kreator pengetahuan (Egan dan Bloome via Menacker, 1998: 2).

Bahasa dan pemikiran tidak akan pernah bisa dipisahkan. "learn a new language and get a new soul" (belajar bahasa baru akan mendapatkan jiwa baru) merupakan semboyan yang dinyatakan oleh Czeh (via Halpern, 2003: 106). Diskusi tentang telaah kuasa bahasa juga menjadi kegiatan yang sering dilakukan untuk mengkaji dan memaknai teks. Beberapa penelitian tentang CLA juga dilakukan yang dapat dilihat dari beberapa buku seperti "The Language of Africa and The Diaspora:Educating for language Awareness" yang menguaraikan tentang pengajaran Language Awareness di Guadaloupe (Kleifgen dan Bond: 2009) serta Linguistic Awareness in Multilinguals oleh Ulrike Jessner (2006) yang mengkaji metalinguistics awareness atau kesadaran metalinguistik.

Menulis merupakan kegiatan yang sangat dianjurkan untuk menumbuhkan respon terhadap kemampuan Kesadaran Berbahasa Kritis. Hal ini dikarenakan dalam menulis, penulis akan memunculkan identitasnya dengan mengaitkan pandangan, gagasan, dan posisinya dalam konteks sosiokultural yang ada di sekitarnya. Sebelumnya keterampilan menulis hanya diarahkan pada kemampuan menulis dasar. Melalui pendekatan CLA, kegiatan menulis dipandang sebagai kegiatan menyeluruh yang meliputi dimensi sosial, budaya, politik, termasuk respon terhadap kebijakan strategis dan birokratik. Dari pemahaman ini dan juga teori tentang kuasa bahasa, serta penelitian-penelitian yang terkait dengan kesadaran berbahasa penelitian tentang CLA menjadi penting untuk dilakukan.

Dalam praktiknya, CLA dalam keterampilan seperti yang telah dilakukan oleh Clarks dan Fairclaugh (dalam Fairclaugh, 1992) siswa diarahkan untuk meningkatkan kesadaran tentang proses menulis 
sesudah itu dilanjutkan dengan kegiatan diskusi. Tulisan siswa dianalisis dengan melihat penggunaan kata ganti persona, diksi yang menunjukkan komitmen kuat untuk proposisi, kata dengan intonasi dan bunyi kuat. Dalam penelitian ini, instrumen untuk menilai karya fiksi disusun berdasarkan elemen-elemen tersebut dengan mengkolaborasikan konteks sosiokultur dan politik yang ada dalam masyarakat Indonesia.

Sebuah karya sastra ditampakkan oleh satuan-satuan lingual yang menyatu dan menjalin membentuk wacana yang indah-estetis. Meskipun demikian, karya sastra dibangun oleh unsur-unsur intrinsik yang luas. Antara bahasa dan unsur-unsur intrinsik karya sastra terjadi jalinan yang padu, tak teisahkan. Wujud kebahasaan dalam karya sastra merefleksikan keberadaan unsur intrinsiknya. Sebaliknya, keberadaan unsur karya sastra akan menentukan wujud kebahasaan karya sastra.

Karya sastra ditulis melalui proses menyinergikan unsur kesastraan dan kebahasaan, dan itu bukanlah hal yang mudah. Ada lima tahap dalam penulisan fiksi yang harus diperhatikan, antara lain: tahap persiapan dan usaha, tahap inkubasi, tahap iluminasi, tahap verifikasi, tahap publikasi. Dalam proses penulisan fiksi, penulis juga akan menemui berbagai kendala. Kendala tersebut dapat dilihat dari wujud karya, aktivitas pada saat berkarya, dan pengakuan dari penulis, baik lisan maupun tulisan.

\section{METODE}

Penelitian ini menggunakan kolaborasi metode analisis konten dan penelitian survei berjenjang dengan penyusunan prototipe berdasarkan pendekatan CLA. Data dianalisis secara kuantitatif dan kualitatif. Analisis data kuantitatif dilakukan untuk menganalisis karya fiksi siswa dan guru yang berkaitan dengan frekuensi kata-kata tertentu yang muncul yang merupakan unsur konsep Kesadaran
Berbahasa secara Kritis (CLA) berdasarkan teori yang dikemukakan oleh Fairclaugh. Analisis data kualitatif dilakukan untuk menginterpretasi teks atau karya fiksi siswa dan guru secara mendalam, cermat, dan sesuai dengan unsur konsep CLA dengan analisis konten (Borg dan Gall, 1983: 514-517).

Analisis data dilakukan dengan berbagai metode. Pertama, analisis konten akan dilakukan untuk mengetahui resepsi kritis kesadaran berbahasa pada karya fiksi guru dan siswa. Kedua, setelah hasil resepsi diketahui analisis selanjutnya akan dilakukan dengan membandingkan data sebelum dan sesudah modul dengan panduan kriteria kesastraan dengan menggunakan pendekatan CLA. Selain itu, untuk data hasil wawancara, diskusi, dan catatan lapangan dianalisis dengan teknik analisis deskriptif kualitatif. Hasil analisis kualitatif mendasari revisi dan penyempurnaan modul.

Untuk mencapai validitas dan reliabilitas penelitian khususnya pada rancangan desain tahun pertama digunakan cek anggota (member check) dan cek orang luar (outsider check). Telaah pakar (expert judgment) juga dilakukan terutama untuk melihat dan menelaah hasil produk karya guru dan siswa. Pakar yang dilibatkan tentu saja yang memiliki keahlian di bidang sastra dan pembelajaran sastra.

\section{HASIL DAN PEMBAHASAN}

Hasil penelitian ini merupakan pemetaan kemampuan resepsi kesadaran berbahasa secara kritis guru dan siswa SMA se-DIY baik ditinjau dari proses maupun produk. Kemampuan guru tertuang dalam Rencana Pelaksanaan Pembelajaran penulisan fiksi yang disusun dengan dilandasi alasan penyusunan serta refleksi terhadap proses pembimbingan penulisan karya fiksi cerpen pada para siswa. Sementara itu, kemampuan siswa tercermin dari kualitas karya yang dihasilkan yakni cerpen. 


\section{Pemetaan Awal Kondisi Pembelajaran Menulis Fiksi di Sekolah}

Kondisi awal pelaksanaan pembelajaran menulis fiksi yang dilakukan oleh guru dan siswa di sekolah tergambar dari respons terhadap kuesioner guru serta hasil diskusi pada tahap satu. Kuesioner yang diberikan oleh guru disusun berdasarkan empat aspek, yakni (a) relevansi kurikulum pembelajaran menulis fiksi dengan kebutuhan dan perkembangan ilmu pengetahuan, (b) metode pembelajaran menulis fiksi, (c) pelaksanaan dan hasil karya pembelajaran menulis fiksi, dan (d) respons terhadap kesadaran berbahasa secara kritis dalam pembelajaran menulis fiksi. Keempat aspek tersebut terurai dalam 28 pertanyaan kuesioner dengan skala likert. Kemudian ada tambahan 2 pertanyaan kuesioner terbuka dengan alasan untuk menggali respons guru secara lebih luas dan mendalam mengenai kendala proses pembelajaran menulis fiksi serta harapan yang diinginkan guru dalam pelaksanaan kegiatan diskusi.

Dari hasil rekapitulasi kuesioner guru untuk, aspek relevansi kurikulum dengan kebutuhan pembelajaran sudah baik, dengan skor rerata 4.26. Dari respons guru ini, dapat diartikan bahwa kurikulum pembelajaran menulis fiksi tidak memerlukan perubahan yang berarti karena sudah sesuai dengan kebutuhan pembelajaran dan perkembangan pengetahuan.

Pada aspek metode pembelajaran, skor rerata pembelajaran menulis fiksi khususnya cerpen menunjukkan hasil yang cukup baik yakni 3.31. Dalam hal ini, metode yang digunakan guru sudah beragam dan menuntun keaktifan siswa, tidak lagi pada teacher-centered. Aspek pelaksanaan pembelajaran dan hasil karya menulis fiksi masih menunjukkan hasil yang minim, yakni dengan skor rerata 1.93. Hasil ini kontras dengan aspek metode pembelajaran. Banyak karya siswa yang belum menunjukkan hasil seperti yang diharapkan. Dari hal ini pula dapat dimaknai bahwa pelaksanaan pembelajaran menulis fiksi masih mengalami banyak kendala yang kemudian berimbas pada hasil karya fiksi siswa.

Sementara itu, skor rerata untuk respons terhadap aspek-aspek kesadaran berbahasa secara kritis juga masih minim, yakni dengan skor rerata 2.15. dari hasil ini, dasar mengapa resepsi kesadaran berbahasa secara kritis perlu mendapat perhatian bagi para praktisi pembelajaran sastra dan kegiatan penyusunan model dan modul penulisan karya fiksi dengan resepsi kesadaran berbahasa secara kritis penting untuk dilakukan.

Berdasarkan tanggapan tertulis guru dalam kuesioner, pembelajaran menulis fiksi di sekolah juga masih mengalami banyak masalah. Pada umumnya siswa kurang memiliki motivasi kuat dalam mengenal beragam cerpen serta menulis cerpen. Hasil karya-karya cerpen siswa pun juga belum menunjukkan hasil seperti yang diharapkan. Respons

Tabel 1. Skor Rerata Respons Awal Guru dalam Pembelajaran Menulis Fiksi

\begin{tabular}{lc}
\hline \multicolumn{1}{c}{ Aspek } & Skor rerata \\
\hline $\begin{array}{l}\text { Relevansi kurikulum pembelajaran menulis fiksi dengan kebutuhan dan } \\
\text { perkembangan ilmu pengetahuan }\end{array}$ & 4.26 \\
Metode pembelajaran menulis fiksi & 3.31 \\
Pelaksanaan dan hasil karya pembelajaran menulis fiksi & 1.93 \\
$\begin{array}{l}\text { Respons terhadap kesadaran berbahasa secara kritis dalam pembelajaran } \\
\text { menulis fiksi }\end{array}$ & 2.15 \\
\hline
\end{tabular}

LITERA, Volume 11, Nomor 1, April 2012 
guru menunjukkan bahwa pembelajaran menulis fiksi masih mengalami banyak kekurangan, baik ditinjau dari lemahnya metode yang digunakan, kurangnya pemanfaatan media, rendahnya budaya baca siswa, kesulitas siswa menuangkan ide, dan lain-lain. Hal ini menjadi bahan kajian dan dasar untuk memperbaiki kualitas pembelajaran khususya menulis fiksi.

\section{Pemetaan Proses Pelaksanaan Pembela- jaran Menulis Fiksi Guru dan Siswa}

Pemetaan proses pelaksanaan penulisan fiksi khususnya cerpen dapat dilihat dari tiga hal, yakni pemahaman guru terhadap resepsi kesadaran berbahasa secara kritis yang merupakan hasil dari ToT yang sudah dilakukan, proses pembuatan RPP, serta pembimbingan terhadap siswa dalam menulis cerpen. Ketiga hal ini terekam dalam Rancangan Pelaksanaan Pembelajaran yang disusun oleh guru serta uraian guru sebagai hasil dari Forum diskusi kedua yang telah dilaksanakan.

RPP menunjukkan proses kegiatan yang akan dilaksanaan dalam pembelajaran di kelas. Dalam menyusun rancangan kegiatan, guru semestinya memiliki dasar yang kuat berkaitan dengan kompetensi dasar yang akan diajarkan, tujuan pembelajaran yang kemudian secara teknis terlihat pada susunan kegiatan awal, inti, dan penutup. Proses pelaksanaan pembelajaran tercermin dalam ketiga rancangan kegiatan ini.

Secara umum, proses pelaksanaan pembelajaran menulis fiksi, dalam hal ini cerpen, yang dilakukan oleh guru sudah memberikan kesempatan bagi siswa untuk terlibat secara aktif. Siswa diposisikan sebagai centre dari pembelajaran. Namun, perlu disadari bahwa menulis fiksi bukan merupakan kegiatan yang dapat dilakukan dalam waktu sekejap dan secara spontan. Guru semestinya membimbing siswa mulai dari menggali ide-ide yang berkaitan dengan permasalahan kehidupan siswa dan masyarakat sekitar kemudian menuangkan ide-ide tersebut yang dipadukan dengan sarana-sarana sastra agar menarik. Pada sebagian RPP yang dirancang guru, guru sudah terlihat menyusun proses kegiatan pembelajaran dengan runtut meskipun ada beberapa yang kurang memberikan arahan kepada siswa khususnya dalam mencari inspirasi sebanyak-banyaknya dan menuntun siswa pada proses berpikir yang kritis.

Media yang dipakai guru dalam proses belajar mengajar beragam. Ada yang menggunakan buku teks, koran, contoh cerpen internet, alam sekitar, dan sebagainya. Namun beberapa RPP menunjukkan bahwa media yang digunakan masih sangat terbatas, yakni hanya menggunakan satu cerpen saja, dari koran atau buku. Padahal untuk mengembangkan inspirasi dan motivasi siswa, banyak hal yang bisa dihadirkan, termasuk menggunakan beberapa cerpen karya-karya terkenal di Indonesia maupun cerpen-cerpen dunia.

Pada umumnya, siswa diarahkan untuk membaca satu cerpen, baik dari buku, koran, maupun internet. Lalu secara individual maupun berkelompok siswa mengidentifikasi unsur-unsur dalam cerpen. Sesudah itu, guru meminta siswa untuk membuat cerpen. Proses pembelajaran seperti ini kurang memberikan ruang bagi siswa untuk mencari inspirasi sebanyakbanyaknya menurut proses berpikir kritis dan kreatif mereka. Unsur-unsur cerpen masih menjadi andalan bagi guru untuk dianalisis misalnya saja watak tokoh, alur, setting, diksi, dan sebagainya. Namun, bagaimana penulis menghadirkan cerita itu, mengapa penulis muncul inspirasi untuk membuat cerpen tersebut, bagaimana fenomena yang terjadi diramu oleh penulis, serta proses-proses kreatif penulis lainnya kurang diperhatikan oleh guru. Hal ini mengakibatkan kurangnya kesadaran bagi siswa untuk memahami proses kreatif penulis yang akhirnya mempengaruhi proses kreatif menulis siswa atau dapat dikatakan proses berpikir siswa menjadi terlalu sederhana. 
Forum diskusi yang dilakasanakan, guru dapat berbagi dan bertukar pengalaman bagaimana pemahaman terhadap resepsi kesadaran berbahasa kritis. Kesadaran terhadap pemanfaatan potensi-potensi dan metode pembelajaran yang berbeda-beda dari masing-masing guru menjadi inti dari uraian tersebut. Pemahaman terhadap resepsi kesadaran berbahasa secara kritis juga menjadikan guru dapat menggali persoalan-persoalan tentang ketimpangan yang ada di sekitar siswa yang dapat menjadi sumber inspirasi penulisan karya cerpen.

Dasar kritis proses penyusunan RPP menjadi poin dalam melihat pemetaan terhadap proses pelaksanaan penulisan fiksi yang ditinjau dari guru. RPP yang dirancang semestinya dilandasi dengan alasan dan daya kritis mengapa merancang pembelajaran seperti yang tertuang dalam RPP. guru menyusun RPP dengan dilandasi kesadaran terhadap kondisi siswa, sarana multiliterasi yang tersedia, serta proses penulisan cerpen yang membutuhkan waktu agal lama. Hal ini menunjukkan bahwa guru sudah berpikir kritis dan sadar terhadap kondisi yang dihadapi yang kemudian menjadi dasar terhadap penyusunan kegiatan pembelajaran yang dilakukan (sesuai konteks).

\section{Pemetaan Hasil Pelaksanaan Pembelaja- ran Menulis Fiksi Guru dan Siswa}

Hasil pelaksanaan penulisan fiksi dalam penelitian ini merupakan produk yang dapat ditinjau dari dua hal, yakni produk dari guru dan produk dari siswa. Produk dari guru berupa Rencana Pelaksanaan Pembelajaran (RPP) terkait kompetensi penulisan fiksi berupa cerpen. Sementara itu, produk dari siswa merupakan karya cerpen hasil pembelajaran menulis fiksi cerpen. Berikut uraian untuk masng-masing produk hasil penelitian. Hasil pelaksanaan juga akan dilihat dari respons guru pada forum diskusi kedua.
Melalui validasi pakar, pemetaan terhadap produk RPP guru dapat dilakukan. Beberapa aspek yang divalidasi merupakan komponen pokok RPP yang kemudian disesuaikan dengan dasar pemikiran kritis dalam menyusun RPP. Hal ini merupakan wujud praktis kesadaran kritis dari guru sehingga RPP yang dirancang bukan hanya sekedar pemenuhan aspek formalitas saja, namun guru hendaknya memiliki kesadaran mengapa merancang pembelajaran sebagaimana yang dituangkan dalam RPP tersebut. Oleh karena itu, para guru diharapkan menulis alasan atau dasar penyusunan RPP.

Selama ini banyak guru yang mengkhawatirkan format RPP yang mereka susun. RPP memang memiliki format khusus yang telah diatur dalam standar penyusunan RPP. Format ini sebenarnya untuk membantu agar susunan RPP runtut dan poin-poin substansial dalam RPP tidak terlewatkan. Namun dalam kenyataannya, banyak guru yang justru meributkan aspek formalitas RPP dan tidak jarang ditemui perbedaan paham mengenai susunan RPP. Lebih buruknya lagi, hal itu berimbas pada aspek substansial RPP yang sering terlewatkan karena aspek formalitas menyita lebih banyak perhatian. Tentu saja, hal ini dapat memberikan efek kurang baik bagi terciptanya rencana pembelajaran yang benar-benar berorientasi pada siswa karena aspek substantif materi kurang diperhatikan.

RPP merupakan wadah bagi guru sebagai bentuk otonomi sekolah dalam memanfaatkan sumber daya untuk meningkatkan kualitas pembelajaran. Guru sebagai pengampu mata pelajaran dapat mengembangkan materi berdasarkan hasil kerja pikir pengembangan ilmu serta pemanfaatan segala sumber daya sekitar termasuk kualitas diri dari guru tersebut. Dari pemahaman ini, maka implikasi yang seharusnya timbul yakni RPP suatu sekolah pasti berbeda dengan sekolah lain karena guru berbeda dan sumber daya 
yang dimanfaatkan pun juga berbeda. Namun, dari hasil evaluasi yang dilakukan, banyak diantara guru yang hanya asal copy paste RPP sekolah lain untuk kepentingan praktis. Maka tidak heran jika RPP di Papua dijumpai ternyata sama dengan RPP di Jogjakarta. Hal ini menjadi bahan diskusi juga pada forum diskusi ilmiah dengan guru.

Forum ToT yang dilaksanakan pada 12 Juli 2011 mengajak para guru untuk menyusun dasar rancangan kerja RPP yang dilandasi dengan kesadaran akan kebutuhan para guru dalam memecahkan masalah yang sering terjadi sekaligus meningkatkan kualitas pembelajaran khususnya dalam penulisan fiksi. Karena jenis karya fiksi bermacam-macam, ada satu jenis fiksi yang dipilih untuk dijadikan orientasi produk yakni cerpen, sebagaimana yang sudah termuat dalam judul penelitian ini. Disamping karena ada Kompetensi Dasar yang dituntut dalam kurikulum terkait penulisan cerpen, karya fiksi berbentuk cerpen memberikan ruang bagi siswa untuk berimajinasi dan mencipta karya sastra yang erat dengan kehidupan mereka sehari-hari, bahasanya ringan, tidak terlalu panjang (dalam hal kuantitas tulisan), serta dapat menjadi media yang sesuai untuk menunjukkan kemampuan siswa.

Hasil validasi pakar menunjukkan bahwa hampir semua RPP yang disusun oleh guru sudah memenuhi kesesuaiannya dengan Standar Kompetensi dan Kompetensi Dasar berdasarkan kurikulum. Hal ini dapat dipahami karena memang di tingkat SMA ada beberapa KD terkait dengan menulis cerpen yang dapat menjadi pilihan guru untuk dikembangkan dengan menyesuaikan tema penelitian ini. hal ini dapat ditunjukkan dalam lampiran mengenai validasi pakar khususnya untuk kesesuaian RPP dengan kurikulum.

Dalam RPP baik secara eksplisit maupun implisit tertuang strategi atau metode pembelajaran yang dilakukan. Komponan ini memiliki andil besar dalam menentukan apakah proses pembelajaran yang dilakukan sesuai, inovatif, berkualitas, dan berfokus pada siswa. Metode-metode pembelajaran dapat dipelajari dari berbagai literatur. Sebagai guru, sudah menjadi keharusan untuk mempelajari berbagai metode pembelajaran agar kelas yang dirancang menyenangkan, Siswa dapat mengeksplorasi kemampuan yang dimiliki dan yang tidak dapat terlewatkan adalah materi pembelajaran dapat disampaikan dengan tepat.

Dalam pembelajaran menulis fiksi, berbagai referensi metode pembelajaran dapat diacu. Metode apa atau metode yang bagaimana yang paling tepat bagi siswa? Tentu saja, metode yang paling tepat adalah yang sesuai dengan tujuan, situasi, kondisi siswa, sarana prasarana serta menginspirasi siswa untuk mampu menulis fiksi khususnya cerpen dengan baik.

Alam, lingkungan, kebiasaan seharihari, peristiwa yang dilihat, berita, dan sebagainya dapat menjadi inspirasi dalam menulis cerpen. Bahkan mimpi pun dapat menjadi media dalam menyampaikan materi yang kemudian menjadi inspirasi menulis cerpen. Metode kontekstual dapat menjadi pilihan bagi guru untuk mengembangkan RPP.

Namun dari hasil validasi ahli, dasar kritis pengembangan metode atau strategi pembelajaran belum tampak baik. Dalam uraian validasi, ternyata "Strategi PBM terlalu global, belum tampak aktivitas nyata langkah-langkah PBM, (metode informasi terlalu umum)". Hal ini dapat diamati pada contoh validasi RPP. Juga dapat dilihat pada contoh validasi lain terkait pengembangan metode pembelajaran menulis fiksi yang dilakukan guru bahwa "Pada aktivitas, masih ada lompatan aktivitas, belum secara runtut. Contoh: siswa diskusi tentang cerpen langsung diminta membuat cerpen". 
Dalam pembelajaran menulis cerpen, media pembelajaran yang dipakai sangat penting terutama untuk memunculkan daya imajinasi siswa. Dari imajinasi itulah siswa dapat memunculkan karya kreatif fiksi karena sebuah karya cipta tidak akan dapat terwujud tanpa adanya imajinasi.

Segala yang ada di sekitar siswa, kelas, atau sekolah dapat menjadi media. Di era sekarang, media internet memberi ruang yang lebih luas bagi siswa untuk mengeksplorasi pengetahuan mengenai segala sesuatu yang dapat digunakan untuk memunculkan daya imajinasi menciptakan cerpen. Sesuai dengan pemahaman terhadap resepsi kesadaran berbahasa secara kritis, alasam mengapa guru memakai media tertentu merupakan aspek penting dalam mengkaji daya kritis guru.

Dari hasil validasi RPP yang telah dilakukan, sebagian besar menunjukkan bahwa "antara media dengan tugas pada siswa tidak relevan". Misalnya, ada RPP yang minta siswa untuk membaca cerpen "Katurangan" karya Slamet Nurzaini untuk tugas tatap muka, namun kegiatan yang dilakukan adalah mencari informasi dari siswa tentang cerpen dari internet.

Beberapa RPP guru menunjukkan pula bahwa media yang digunakan masih konvensional, yakni dengan buku dan koran. Resepsi kesadaran berbahasa secara kritis memberikan pemahaman terhadap guru dan siswa bahwa fenomena atau segala sesuatu yang ada di sekitar adalah media yang penting dan bermanfaat untuk mengembangkan imajinasi siswa. Kejadian yang dijumpai siswa ketika berangkat sekolah, mimpi yang dialami siswa malam sebelum berangkat sekolah, acara-acara televisi yang ditonton siswa, berbagai gambar yang dapat diunduh dari internet, foto-foto siswa ketka mereka pergi bermain dengan keluarga atau teman sebenarnya merupakan media menarik yang sesuai dengan konteks siswa. Dari media-media ini, siswa akan lebih dapat merasakan apa yang etrjadi dan cerita rekaan apa yang akan mereka ciptakan karena siswa mengalami sendiri hal-hal tersebut. guru tampak belum mengekslporasi potensi-potensi yang merupakan pengalaman siswa itu sendiri. Meskipun ada juga guru yang sudah mengajak siswa untuk benar-benar berpikir dengan dilandasi kesadaran kritis untuk menciptakan cerpen. Uraian guru mengenai pembelajaran yang dilakukan sudah menunjukkan proses yang sesuai dengan konsep kesadaran kritis (hal ini akan dibahas pada bagian selanjutnya). Namun dalam $\mathrm{RPP}$, proses yang menunjukkan hal ini kurang tampak sehingga sebagian besar hasil validasi RPP menunjukkan bahwa guru belum dapat memanfaatka media dengan optimal.

Penilaian merupakan bagian penting yang harus dilakukan guru dalam menilai kompetensi siswa yang didasarkan pada tujuan dan indikator keberhasilan pembelajaran. Melalui sistem penilaian yang dilakukan, guru dapat menyimpulkan apakah proses pembelajaran yang dilakukan berhasil atau belum berhasil sehingga harus dilakukan pengulangan maupun pengayaan untuk siswa. Refleksi dari hasil penilaian yang dilakukan guru juga penting untuk perbaikan pembelajaran selanjutnya yang menuntun guru untuk terus berinovasi mengembangkan pembelajaran yang berkualitas.

Dari hasil validasi RPP, dasar kritis peilaian kompetensi siswa dalam menulis cerpen masih menunjukkan beberapa kelemahan, bahkan ada beberapa RPP yang tidak mencantumkan cara penilaian atau biasa disebut dalam poin evaluasi pembelajaran. Sebagian besar RPP menunjukkan sistem penilaian yang dilakukan masih terlalu general, hanya melihat pada aspek isi dan bahasa saja.

Penilaian yang dilakukan guru dapat tercermin juga dalam latihan-latihan yang diberikan. Tugas individu maupun kelompok dapat digunakan guru, namun seharusya perlu diuraikan lebih lanjut 
macam tugas apa yang diminta sebagai tagihan dari siswa.

Pemahaman terhadap resepsi kesadaran berbahasa secara kritis menuntun guru untuk memahami kesadaran kritis terhadap keseluruhan aspek pembelajaran. Kompetensi dasar dan tujuan pembelajaran menjadi kunci penting dalam menentukan bagaimana sistem penilaian yang seharusnya dilakukan oleh guru karena penilaian sendiri harus didasarkan pada indikator pencapaian kompetensi yang harus dikuasai siswa serta apa tujuan pembelajaran yang dilakukan. Hal ini tampaknya belum disadari sepenuhnya oleh guru.

\section{Produk Cerpen Karya Siswa}

Cerpen karya siswa menjadi bahan kajian penting dalam melihat keberhasilan guru dan resepsi siswa dalam penulisan karya fiksi cerpen. Guru melakukan pembimbingan pada siswa untuk menulis karya fiksi dengan dilandasi kesadaran berbahasa secara kritis dan siswa memberikan respons dengan menuliskan daya kreativitasnya dalam menulis cerpen.
Ada 70 cerpen siswa yang terkumpul sebagai produk pembelajaran menulis fiksi cerpen. Validasi cerpen dilakukan oleh ahli pembelajaran sastra terhadap beberapa aspek kesadaran berbahasa secara kritis. namun begitu, penilaian terhadap cerpen secara umum juga dilakukan.

Aspek penilaian cerpen dengan resepsi kesadaran berbahasa secara kritis didasarkan pada dimensi kesadaran kritis yang disesuaikan dengan kompetensi penulisan karya fiksi. Aspek yang dinilai meliputi (1) penggunaan sarana bahasa untuk kekuatan cerita, (2) kepekaan terhadap pergeseran bahasa, (3) komitmen penulis pada proposisi, (4) pemetaan diri terhadap lingkungan sosial, budaya, politik, (5) pemetaan masyarakt sebagai bagian dari diri penulis, kesadaran terhadap emansipasi dan demokrasi, dan (6) kesadaran terhadap relevansi cerita dengan kehidupan.

Aspek-aspek di atas memang sangat kompleks dan tentunya membutuhkan kecrematan dalam melakukan penilaian. Oleh karena itu, hal ini menjadi kerja besar bagi validator untuk melihat kualitas

Si Bocah penjual Koran, berlarian kecil menghampiri sebuah truk kuning pengangkut barang. Ia menengadah, memandang gelagat sopir gemuk dengan sebuah batang rokok disela mulutnya.

“Korannnya pak" tawar si bocah sembari mengangkat tinggi Koran jajakannya.

"Tidak dek." Ujar sopir itu begitu santainya "Dari pada kamu jualan Koran, ya mbok sekolah tho dek." Kemudiam menghisap kembali rokoknya, deng menyembulkan asapnya ke udara.

"Tidak ada biaya pak, bapak saya cuma seorang kuli." Jawab bocah itu dengan wajah penuh harap si sopir akan membeli korannya.

"Oalah, gendheng. Jogja iki kota pendidikan, tetep ora ethis ana bocah ora sekolah malah kluyuran neng dalan." Sahut si sopir "Lha, pemerintah ada bantuan untuk anak-anak yang tidak mampu, kalau tidak bisa kamu manfaatkan, gimana tidak dikorupsi sama pejabat?!"

Vignet 1 Contoh Penggalan Cerpen Siswa 
cerpen siswa yang disesuaikan dengan konsep resepsi kesadaran berbahasa secara kritis.

Hasil validasi menunjukkan bahwa ada beberapa cerpen siswa yang sudah menunjukkan kekuatan bahasa dan pemetaan diri siswa di tengah lingkungan sosialnya, misalnya saja pada cerpen "Bintang yang Jatuh", "Diary depresiku”, "Hanya Kisah Hanya Suara", "Arti Persahabatan". Cerpen-cerpen tersebut berisikan ekspresi siswa terhadap segala perasaan yang mereka miliki maupun respons terhadap fenomena sosial di sekitar mereka dengan memanfaatkan unsur budaya yakni budaya jawa. Contoh dapat dicermati pada penggalan kisah cerpen "Hanya Kisah Hanya Suara" pada vignet 1 .

Dari hasil validasi ahli, sebagian besar cerpen mengangkat tema-tema konvensional. Konflik yang dihadirkan pun kurang tajam sehingga kemenarikan cerita menjadi kurang. Hal ini dapat menjadi refleksi bagi guru untuk melakukan refleksi dan perbaikan proses pembelajaran. Dari Forum diskusi kedua yang dilaksanakan, kesadaran guru terhadap kekurangan inipun juga muncul.

- Siswa sebenarnya punya motivasi kuat menulis

- Kelemahan: konflik kurang tajam

- Anjuran ke siswa: buatlah cerpen yang lain dengan yang lain, berkesan, merubah konvensi, dekonstruksi

Vignet 2. Tanggapan Guru terhadap Kemampuan Siswa Menulis Cerpen

Tanggapan pada vignet 2 merupakan tanggapan dari Bu Indri, salah satu peserta diskusi. Kemudian oleh peserta lain yang mendasarkan masalah pada kurangnya minat baca siswa sehingga mereka belum memiliki referensi untuk mengembangkan cerita agar menarik dan mencapai konflik yang tajam.

\section{Respons Guru terhadap Pembelajaran Menulis Fiksi dengan Kesadaran Berba- hasa secara Kritis}

Dari diskusi kedua yang diselenggarakan, kesadaran dan respons guru terhadap pelaksanaan pembelajaran menulis fiksi dengan kesadaran berbahasa secara kritis terlihat dari uraian mereka mengenai bagaimana proses pelaksanaan penulisan cerpen yang harus dilaksanakan dengan konsep kesadaran berbahasa secara kritis.

Dari uraian guru pemanfaatan media seperti musik, video klip dapat digunakan oleh guru untuk merangsang daya imajinasi siswa dalam menulis cerpen. Proses pembimbingan pun semestinya dilakukan dengan menyesuaikan kondisi siswa serta kelas harus dirancang agar menyenangkan.

Namun ada pula hasil refleksi guru yang perlu dipertimbangkan yakni mengenai kebutuhan terhadap waktu. Proses pembimbingan dari mulai penyampaian materi sampai pada penciptaan produk dan penilaian membutuhkan waktu yang tidak sedikit. Menumbuhkan kepekaan dan siswa tentunya tidak dapat dilakukan secara instan. Kesadaran harus berasal dari refleksi dan kerja pikir yang didasarkan pada pengalaman hidup siswa sendiri.

Forum diskusi memberikan ruang bagi para guru sekaligus peneliti untuk saling berbagi. Beberapa masukan, referensi yang kemudian menuntun pada refleksi dari masing-masing guru sekaligus peneliti muncul dalam diskusi. Hal ini memberikan manfaat yang begitu besar khususnya sebaai bahan kajian utuk mengembangkan lebih lajut pembelajaran menulis fiksi khususnya cerpen agar lebih berkualitas. 


\section{Kemampuan Guru dan Siswa dalam Penulisan Karya Fiksi}

Permasalahan pembelajaran bahasa dan sastra memang tidak pernah ada akhirnya. Hal ini dapat dipahami karena bahasa dan sastra selalu berkembang seiring dengan perkembangan masyarakat. Bahasa merupakan media komunikasi sosial masyarakat dalam menyampaikan ide, gagasa, pemikiran kepada sesama. Sementara itu, sastra dapat dipandang sebagai representasi dari masyarakat itu sendiri. Tidak berlebihan jika sastra dianggap sebagai salah satu artefak masyarakat yang juga merupakan bagian dari hasil budidaya manusia.

Melalui sastra, pola kehidupan, pandangan, pola pikir, dan perkembangan keilmuan masyarakat dapat diketahui. Ekspresi, luapan perasaan, ataupun tanggapan seorang penulis terhadap fenomena sekitar akan tercermin dalam karya sastra. Dari sinilah, identifikasi terhadap era, semangat zaman, maupun realitas sosial masyarakat dapat dilakukan.

Dalam bidang pendidikan pun khususnya pembelajaran sastra, siswa sebagai penulis sastra harus mampu menghadirkan gambaran-gambaran realitas sosial dan ekspresi diri mereka. Tentu saja ekspresi ini akan terkait dengan perkembangan psikologis siswa yang sudah kaya dengan pengalaman-pengalaman sejak kecil. Sumber inspirasi menulis cerita dapat berasal dari mana saja.

Melalui berbagai sarana-prasarana yang tersedia sekarang, pengetahuan dunia dapat diperoleh dari manapun. Internet misalnya, telah menjadi alat untuk membuka pintu-pintu wawasan atas segala yang terjadi di seluruh tempat di dunia. Semuanya dapat diperoleh dengan lengkap. Maka, dengan tersedianya fasilitas ini, tidak ada alasan bagi para siswa maupun praktisi pendidikan untuk tidak mengetahui berita-berita atau kejadian yang berkaitan dengan realitas sosial masyarakat dunia.
Guru pun dapat memanfaatkan berbagai media yang telah tersedia. Materi dari koran, internet, buku, dan sumbersumber lain dapat menjadi pegangan dalam membimbing siswa bagaimana berproses kreatif sastra yang baik, artinya pemahaman dan dasar kritis penyusunan karya sastra lebih dikedepankan daripada hanya sekedar berorientasi pada produk akhir saja.

Dari data hasil penelitian yang diperoleh, kemampuan guru dan siswa dalam penulisan karya fiksi ditinjau baik secara proses maupun produk. Secara proses, guru melakukan studi, mengkaji, ilmi penulisan sastra atau karya fiksi, dalam hal ini cerpen melalui berbagai sumber. Guru juga melakukan diskusi ilmiah untuk berbagi dan melakukan brainstorming pembelajaran menulis fiksi yang mereka laksanakan maupun yang ideal untuk diaplikasikan dalam kelas.

Dari telaah ahli dan kajian yang komprehensif yang dilakukan, proses yang dilakukan oleh guru dalam membelajarkan keterampilan menulis cerpen memang masih menemui banyak kendala. Umumnya, kendala ini terkait dengan motivasi siswa untuk menulis yang kurang serta minat baca siswa yang terlalu rendah.

Membangkitkan motivasi menulis cerpen memang bukan sesuatu hal yang mudah. Guru harus melakukan identifikasi terhadap pribadi siswa, apa yang membuat siswa tidak tertarik menulis cerpen, dan kemudian merancang metode yang tepat dan menarik minat siswa dengan memanfaatkan berbagai media pembelajaran yang ada. Hal ini tercermin dari dasar penyusunan RPP guru serta kegiatan yang dirancang dalam RPP dengan memanfaatkan berbagai media yang digunakan.

Permasalahan lain juga terkait dengan kemampuan guru meramu dan merancang pembelajaran. Mengenal karakter siswa, mengakses pengetahuan yang sesuai dengan minat siswa dan perkem- 
- Siswa (kemampuan menulis cerpen) sebenarnya setiap siswa itu berbeda-beda, bagi yang belum bisa atau tidak ada minat kami selaku guru selalu memberi motovasi dan selalu menunukkan hasilnya, kemudian anak itu akan termotivasi untuk menulis karena pendekatan guru dan bimbingan yang tidak pernah bosan-bosan

- Proses pembuatan RPP sebenarnya sudah kewajiban kita sebagai guru dan itu pasti ada, Cuma kita harus selalu mengembangkan RPP itu, baik materi maupun contohcontohnya.

Vignet 3. Contoh Refleksi Proses oleh Guru

- Ternyata setelah mendengarkan pengalaman guru-guru, saya dapat menyimpulkan bahwa masing-masing guru punya cara yang unik. Tujuannya sama, siswa dapat membuat produk.

- Dengan cara pemodelan, tunjukkan beberapa cerpen. Kiteria cerpen dan unsurunsurnya. Beri semangat, beri kemungkinan memunculkan gagasan baik pengalaman pribadi atau orang lain.

Vignet 4. Contoh Refleksi Proses oleh Guru

bangan psikologis siswa juga membutuhkan ilmu yang tentunya harus dikuasai oleh guru. Pembelajaran yang monoton, terlalu banyak ceramah tentu saja tidak sesuai dengan kebutuhan pembalajaran menulis fiksi.

Namun dari kajian terhadap refleksi diri para guru, proses yang dilakukan guru dalam membimbing proses kreatif siswa setelah mengikuti workshop sudah lebih baik. Contoh refleksi guru dapat dicermati pada vignet 3 .

Vignet 3 terlihat bahwa guru sudah melakukan identifikasi dan refleksi terhadap kebutuhan pembelajaran menulis cerpen. Ada beberapa hal yang semestinya menjadi kemampuan dasar yang harus dikuasai guru, selain juga kemampuankemampuan lain yang harus dikembangkan. Kesadaran guru terhadap pengembangan RPP juga sudah tampak. Hal ini mengindikasikan dampak yang positif dari pengalaman mengajar guru dan hasil sharing bersama dalam diskusi.

Respons lain dari perbaikan secara proses yang dilakukan oleh guru dapat dicermati pula dalam contoh vignet 4 .
Pengetahuan guru terhadap berbagai cara membelajarkan sastra dapat menjadi modal yang sangat besar untuk menyusun metode dan memanfaatkan media pembelajaran yang tepat. Dengan referensi yang beragam ini, guru menjadi lebih inovatif mengembangan model-model pembalajaran menulis sastra atau fiksi yang harapannya dapat meningkatkan kualitas pembelajaran baik secara proses maupun produk.

Bagi siswa, proses menulis fiksi cerpen mungkin menjadi mudah, namun banyak juga yang beranggapan kegiatan ini sulit dilakukan. dari respons dan jawaban guru, kendala terbesar dari siswa adalah kurangnya minat baca. Dari membaca berbagai jenis karya sastra, sebenarnya siswa akan mengetahui bagaimana seorang penulis menghadirkan kejuta, menonjolkan karakter tokoh, membuat alur yang mengalir dan selalu menimbulkan rasa ingin tahu pembaca. Dengan membaca dan memplejarai cerpen-cerpen yang berkualitas, siswa dapat mengenal bagaimana cerpen yang baik dapat dihasilkan oleh 
seorang penulis. Ketika minat baca renda, atau bahkan siswa belum pernah membaca cerpen proses dan pengetahuan berpikir tersebut tidak terlibat dalam tahap proses kreatif menulis cerpen. Akibatnya, karya siswa menjadi sangat biasa, tidak mampu menghadirkan sesuatu yang unik dan menarik hati pembaca, bahkan cerita hanya dangkal saja.

Dari tinjauan produk, karya siswa banyak yang sudah menggambarkan ekspresi jiwa dan respons terhadap fenomena sekitar. Kriteria yang dipakai memang diperuntukkan bagi siswa SMA. Dari hasil validasi ahli, cerpen-cerpen karya siswa banyak yang masih terkesan dangkal. Namun beberapa karya cerpen sudah menunjukkan hasil yang sangat memuaskan.

\section{Pemetaan Resepsi Kesadaran Berba- hasa secara Kritis Karya Fiksi Guru dan Siswa}

Melalui pemahaman bahwa sastra merupakan representasi respons manusia terhadap lingkungan pribadi, sosial, masyarakat, maupun dunia global inilah kesadaran berbahasa secara kritis menjadi hal penting yang harus dipertimbangkan dalam proses penyusunan karya fiksi.

Seperti yang telah dinyatakan di bagian sebelumnya bahwa pemetaan terhadap resepsi kesadaran berbahasa secara kritis untuk guru tercermin terutama dari produk RPP yang disusun. RPP ini dikaji dengan mempertimbangkan beberapa aspek konsep teoretis kesadaran berbahasa secara kritis yang disesuaikan dengan komponen-komponen dalam RPP. Adapun aspek-aspek yang dikaji dalam RPP, yakni (a) kesesuaian RPP dengan kurikulum, (b) dasar kritis pengembangan metode/strategi pembelajaran, (c) dasar kritis pemanfaatan media pembelajaran, dan (d) dasar kritis penilaian karya siswa

Penentuan keempat aspek di atas didasarkan pada kajian komprehensif RPP yanag bertolak dari landasan konseptual dan prosedural, khususnya pada aspek kesesuaian RPP dengan kurikulum. kemudian, aspek selanjutnya yakni dasar kritis pengembangan strategi dan metode pembelajaran berkaitan dengan pelaksanaan pembelajaran yang dilakukan oleh guru dan siswa. Guru semestinya memiliki landasan kuat dalam memilih metode atau strategi pemebelajaran yang tepat.

Banyak sekali strategi maupun metode pembelajaran menulis fiksi. Satu hal yang harus dipahami bahwa tidak ada metode yang paling bagus baik. Namun, metode yang sesuai dengan kebutuhan pembelajaran dan tersediaya saranalah yang paling tepat untuk dipilih, tentu saja dengan mempertimbangkan jenis atau topik materi yang disampakan. Oleh karena itu, dasar kritis mengapa guru memilih strategi atau metode pembelajaran semestinya menjadi bagian dari resepsi kesadaran berbahasa secara kritis guru juga.

Dari data yang diperoleh, masingmasing guru memang memiliki keunikan dan cara sendiri dalam membelajarkan menulis cerpen. Ada yang dengan mengajak siswa keluar kelas/ruangan kemudian meminta siswa untukmencari inspirasi dan menuliskan inspirasinya ke dalam sebuah cerpen. Ada guru yang memilih metode modelling yakni dengan mengajak siswa membaca cerpen kemudian menganalisis unsur-unsur yang ada dalam cerpen. Sesudah itu siswa diminta untuk menulis cerpen mereka. ada pula guru yang memberikan kebebasan kepada siswa untuk memiliih cerpen dari internet, buku, atau koran kemudian menganalisis unsur-unsurnya. Sejauh metode ini memang dapat diikuti siswa dan menjadikan kelas menyenangkan sehingga dapat menarik minat siswa, guru dapat mengembangkan lebih lanjut penerapan strategi tersebut. Tentu saja, guru juga harus senantiasa melakukan refleksi terhadap proses pembelajaran 
yang dilakukan, apakah sudah tepat atau belum, atau masih perlu perbaikan.

Di era multiliterasi ini, paradigma yang berkembang dalam pembelajaran baca-tulis (literasi) yakni adanya sarana literasi yang beragam (multi) yang dapat dimanfaatkan guru dan siswa dalam proses belajar mengajar. Sarana literlahasi yang dimaksud dapat dijadikan media dalam pembelajaran. Pemanfaatan media memang sangat penting dalam menciptakan suasan belajar yang menyenangkan, innovatif, dan inspiratif. Apalagi dalam pembelajaran menulis kreatif fiksi, media yang dipakai harus mampu membangkitkan inspirasi dan motivasi siswa dalam menemukan ide dan mengembangkan cerita.

Dari hasil telaah dasar kritis penggunaan media, banyak guru yang belum memanfaatkan media dengan maksimaal. Dalam pembelajaran menulis cerpen, media yang dipakai tidak hanya terbatas pada contoh cerpen saja. Hal ini dikarenakan akan berdampak kurang baik pada siswa yang memang tidak menyukai cerpen. Guru dapat memakai media yang erat dengan kehidupan siswa, misalnya saja kartu mimpi, kartu ucapan ulang tahum, pengalaman ketika beragkat ke sekolah, diary, foto, facebook, dan sebagainya. Tampaknya pemnafaatan media pembelajaran masih menjadi kelemahan dari sebagian besar para guru sehingga siswa menjadi kurang tertarik dengan membaca dan menulis cerpen.

Menentukan aspek-aspek penilaian kualitas baik proses maupun produk dalam pembelajaran menulis memang bukan merupakan hal yang mudah. Guru hatus memiliki landasan konseptual dna teoretis yang jelas mengenai materi serta bagaimana sistem penilaian yang sesuai dengan tujuan pembelajaran dan materi yang disampaikan. Hal ini menjadi kelemahan sebagian besar guru yang kurang menguasai sistem penilaian dengan baik. Jika kualitas cerpen siswa hanya ditentu- kan dari unsur-unsur pembangun cerita seperti alur, penokohan, setting, dan lainlain maka nantinya karya siswa hanya akan menjadi karya yang biasa tanpa didasari pada pemahaman kritis terhadap fenomena yang terjadi di kehidupannya.

Penilaian terhadap karya siswa untuk mengkaji kualitas cerpen didasarkan pada penilaian cerbeberapa elemepen secara umum dan penilaian menurut elemen kesadaran berbahasa secara kritis. Aspekaspek penilaian cerpen mancakup dua hal, yaitu (a) Penilaian cerpen secara umum, terdiri dari kemenarikan judul, penggunaan bahasa figurative, penciptaan alur cerita, penggunaan setting, penggambaran tokoh, dan kedalaman makna; dan (b) penilaian cerpen dengan kesadaran berbahasa secara kritis, terdiri dari penggunaan sarana bahasa untuk kekuatan cerita, kepekaan terhadap pergeseran bahasa, komitmen penulis pada proposisi, pemetaan diri terhadap lingkungan sosial budaya politik, pemetaan masyarakat sebagai bagian dari diri penulis, kesadaran terhadap emansipasi dan demokrasi, dan kesadaran terhadap relevansi cerita dengan kehidupan

Dari hasil telaah produk cerpen karya siswa, untuk penilaian cerpen secara umum pada dasarnya hampir semua karya siswa sudah memenuhi aspekaspek tersebut. namun, aspek-aspek dalam kesadaran berbahasa secara kritis belum tampak jelas pada sebagian besar karya siswa. Dalam proses kreatif menulis, siswa berdiri dan berposisi sebagai penulis yang kaya akan berbagai pengalaman, pengamat yang memiliki referensi pengetahuan yang berbeda setiap hari, serta pengarang cerita yang memiliki kekuatn untuk mengajak pembaca dan mempengaruhi pembaca masuk ke alam dunia pikiran penulis. Oleh karena itu, sarana-sarana pembangun kekuatan yang dihadirkan dalam cerita harus dapat menjadi alat yang tepat untuk membangun kekuatan penulis. Dengan kata lain, 
proposisi yang dimunculkan harus didukung oleh sarana kebahasaan yang kuat.

Siswa sebagai penulis harus dengan sadar mengerti dan memahami fenomena di sekitar mereka. Oleh karena itu, posisi penulis dalam lingkungan sosial, budaya, dan politik harus jelas juga. Dengan kepekaan pengamatan siswa, cerita pendek yang dibangun tidak akan "berada di atas awan", namun cerita tersbeut hidup dalam lingkungn penulis dan pembaca sehingga cerita akan lebih mudah diterima, mudah dicerna, menimbulkan ketertarikan untuk terus menerus membaca, dan tentu saja sarat akan nilai-nilai kehidupan.

\section{Rancangan Materi dan Modul Menulis Fiksi untuk Guru dan Siswa}

Pembahasan mengenai racangan materu dan modul menulis fiksi merupakan bagian dari tujuan penelitian. Gambaran awal bagaimana materi dan modul yang akan disusun sebenarnya bertolak dari hasil pemetaan terhadap proses dan produk penelitian baik dari proses yang dilakukan guru dan peneliti dalam diskusi, proses guru dalam pembelajaran dan pembimbigan siswa, proses siswa dalam menulis cerpen, produk RPP guru, maupun produk karya cerpen siswa.

Dari hasil penelitian yang diperoleh, satu kesimpulan yang dapat ditarik sebagai dasar pengembangan materi dan modul menulis fiksi adalah bahwa perlu adanya petunjuk praktis dan sederhana bagi guru dan siswa sehingga materi dan modul tersebut dapat diaplikasikan secara mandiri oleh guru dan siswa di sekolah. Modul yang disusun secara komunikatif dan inspiratif sehingga kesadaran kritis guru dan siswa akna terbangun.

Penyusunan materi dan modul merupakan agenda penelitian pada tahun kedua. Oleh karena itu, bahasan bagian ini tidak diuraikan secara lengkap karena pada tahun pertama penelitian hanya berupa identifikasi terhadap materi dan modul yang sesuai dan komprehensif dengan mempertimbangan kebutuhan pemenuhan kurikulum, kompetensi yang harus dikuasai siswa, kemudahan guru dalam membelajarkan materi dan modul, kemudahan siswa dalam mempelajari modul, serta kualitas modul itu sendiri.

\section{SIMPULAN DAN SARAN}

Beberapa kesimpulan yang dapat ditarik dalam penelitian ini adalah sebagai berikut. Pertama, kemampuan guru dan siswa dalam menulis fiksi masih mengalami banyak kendala. Kendala tersebut dapat berasal dati guru yang memiliki keterbatasan dalam mengembangkan metode pembelajaran yang umumnya masih monoton. Namun dari diskusi yang dilakukan, pemahaman terhadap beragam metode dapat menginspirasi guru untuk merancang pembelajaran yang lebih inovatif. Sementara itu, kemampuan siswa masih terkendala dengan lemahnya motivasi menulis dan minat baca siswa yang berdampak pada kualitas karya siswa yang kurang optimal. Kedua, resepsi kesadaran berbahasa secara kritis guru dan siswa dalam menulis fiksi tercermin baik dalam proses maupun hasil. Dari kajian proses dan hasil pihak guru, dasar kritis pengembangan metode, pemanfaatan media, dan pemilihan sistem penilaian masih kurang optimal. Pada proses dan karya siswa, secara umum karya siswa sudah baik, namun jika ditinjau dari aspek kesadaran berbahasa secara kritis, sebagian besar karya siswa belum menampakkan kesadaran pentingnya kekuatan bahasa dan posisi diri siswa sebagai penulis. Ketiga, materi dan modul penulisan karya fiksi dengan kesadaran berbahasa secara kritis harus dirancang dengan sederhana, praktis, komunikatif, dan inspiratif sehingga dapat dengan mudah diaplikasikan oleh guru dan siswa.

Saran untuk dapat diberikan dari hasil kajian penelitian ini adalah sebagai berikut. Pertama, perlu diadakan forumforum diskusi sejenis sebagai tindak lanjut 
dari diskusi pembelajaran sastra. Kedua, guru diharapkan senantiasa aktif dalam berbagai kegiatan training yang berguna untuk pengembangan keilmuan. Ketiga, pelu dirancang sebuah program yang mampu membangkitkan minat baca siswa sehingga mereka tidak terbelenggu inspirasi proses kreatif menulis hanya karena kekurangan bahan literatur.

\section{UCAPAN TERIMA KASIH}

Pada kesempatan ini kami ingin menyampaikan terima kasih kepada beberapa pihak yang telah membantu terselenggaranya penelitian ini. Pertama, ucapan terima kasih kami sampaikan kepada Direktur DP2M Dikti yang telah menyeponsori penelitian dan memberikan dana Hibah Bersaing tahun 2010. Kedua, terima kasih kami ucapkan kepada Rektor UNY melalui Lembaga Penelitian UNY yang telah memfasilitasi penelitian ini hingga semua proses dapat berjalan sesuai ketentuan. Selanjutnya, kami ucapkan terima kasih kepada tim validator, guru-guru yang tergabung dalam MGMP Bahasa Indonesia SMP se-DIY, staf administrasi Lemlit UNY, serta pihak-pihak lain yang tidak dapat kami sebutkan satu per satu. Harapan kami penelitian ini dapat memberikan manfaat bagi segenap kalangan civitas akademika, peningkatan kualitas pembelajaran bahasa Indonesia pada khususnya, dan penigkatan keilmuan berbasis penelitian.

\section{DAFTAR PUSTAKA}

Ardianto. 2007. Pembelajaran Sastra sebagai Sarana Pengembangan Daya Nalar Manusia,Iqra, volume 3 Januari-Juni. Manado

Borg, Walter R. \& Meredith D. Gall. 1983. Educational Research: An Introduction. New York: Longman.

Dewantara, Ki Hajar. 2009. Мепијu Manusia Merdeka. Yogyakarta: Leutika.

Fairclaugh, Norman. 1995. Critical Discourse Analysis: The Critical Study of Language. USA: Longman.
Fairclaugh, Norman.. 1999. “Global Capitalism and Critical Awareness of Language" dalam jurnal Language Awareness volume 8. www.scribd. co/doc/274032/critical-awareness-oflanguage.

Greene dan Perkins, 2003. Making Race Visible: Literary Research for Cultural Understanding. New York: Teacher College, Columbia University.

Halpern, Diana F. Thought \& Knowledge: An Introduction to Critical Thinking. New Jersey: Lawrence Erlbaum Associates Inc.

Jessner, Ulrike. 2006. Linguistic Awareness in Multilinguals. Edinburgh: Edinburgh University Press Ltd.

Kleifgen, Jo Anne and George C. Bond. 2009. The Language of Africa and The Diaspora:Educating for language Awareness. Great Britain: MPG Books Ltd.

Marahimin, Ismail. 2001. Menulis Secara Populer. Jakarta: Pustaka Jaya

Menacker, Terri. 1998. Active Critical Language Awareness: An Innovative Approach to Language Pedagogy. Department of Hawai, University of Hawai.

Rosa, Helvy Tiana. 2003. Segenggam Gumam. Bandung: Tamadun.

Sanchez, Deborah. 2008. "Critical Language Awareness and Learners in College Transition English". Urbana: National Council of English Teacher. www.proquest.umi.pqd/web.

Sayuti, Suminto A. 2000. Berkenalan dengan Prosa Fiksi. Yogyakarta : Gama Media Sayuti, Suminto A. dkk. 2007. "Pengembangan Model Pembinaan Menulis Karya Sastra Anak dan Remaja", Laporan Penelitian Hibah Bersaing Tahun Pertama.

Suryaman, Maman. 2003. “Kemampuan Baca Siswa SLTP di Kabupaten dan Kota Bandung" Riset dijurnalkan dalam Litera Volume II, Nomor 1, Januari 2003.

Suyata dalam Ma'arif, Ahmad Syafi'I, dkk. 2006. Kearifan Sang Profesor: 
Bersuku-suku untuk Kenal-mengenal. Yogyakarta: UNY Press.

Svalberg, Agneta, M-L. 2007. “Language Awareness and Language Learning" dalam Language Teaching volume 40. www.proquest.umi.pqd/web.
Yood, Jessica. 2005. "Present-Process: The Composition of Change". Journal of Basic Writing Fall Volume 24. www. proquest.umi.pqd/web 